\title{
BANTUAN KEMANUSIAAN AUSTRALIA TERHADAP PENGUNGSI
}

\section{SURIAH}

Isman Habibillah, S.IP

Alumni Jurusan Hubungan Internasional Universitas Wahid Hasyim Smarang dan

Relawan di Global Peace Foundation Indonesia

Email : isman1945@gmail.com

\begin{abstract}
This article analyzes Australian foreign policy relating to humanitarian aid to Syria. Foreign policy is the formulation of a policy that is the result of a combination of domestic conditions (domestic factors) and the constellation of international politics (global factors). Likewise with Australian foreign policy. In the formulation of the implementation of foreign policy, certainly consider the domestic factors and the international political constellation that occurred at that time so that the policy formulated will be able to realize Australia's national interests. To show Australia's concerns about the disruption by the Syrian regime's violence against its people, Australia imposed new sanctions on Syria on 21 August 2012 restricting the trading of precious metals and diamonds, luxury goods, and newly minted currencies as well as to the oil, gas and petrochemical sectors. New measures add to the freezing of existing assets and travel restrictions on 106 individuals and 28 entities and an embargo on the supply of military equipment and assistance. Australian sanctions specifically target the regime, not the Syrian people. including sanctions against senior government figures, including President Assad, who is connected with violence and human rights abuses. The research method used is qualitative research method, that is make description, picture or painting systematically, factual, accurate about facts, properties and relationship between phenomena investigated.
\end{abstract}

Keywords: Australian Foreign Policy, Syrian Crisis, Humanitarian Aid

\section{A. PENDAHULUAN}

Krisis Suriah pecah tahun 2011 akibat serangan luas kelompok-kelompok teroris dukungan Arab Saudi, Amerika Serikat dan sekutu-sekutunya termasuk Turki untuk menggulingkan pemerintahan konstitusional Bashar Al Assad, Presiden Suriah. Pemerintah Australia menyesalkan kekerasan dan penderitaan yang terjadi di Suriah. Australia mengutuk semua tindakan kekerasan terhadap warga sipil, siapa yang 
bertanggung jawab. Pemerintah tetap berkomitmen untuk merespon situasi internasional di Suriah. Australia terus bekerja dengan negara-negara yang mempunyai tujuan yang sama untuk menjaga tekanan pada pemerintah Suriah untuk mengakhiri kekerasan dan berkomitmen secara inklusif untuk proses transisi politik. Menteri Luar Negeri Australia menyatakan untuk menyelesaikan krisis Suriah tidak ada opsi lain kecuali mempertahankan Bashar Al Assad sebagai presiden negara itu.

Bahkan Pemerintah Australia mulai menerapkan uji coba pemberian visa gratis bagi beberapa pengungsi asal Suriah dan keluarganya, dimana mereka tidak harus membayar biaya pemrosesan visa. Para pengungsi in harus terlebih dahulu mendapat sponsor dari bisnis yang berada di Australia dan memenuhi kriteria memiliki ketrampilan dan juga pemeriksaan berkelakuan baik. Pemerintah Australia sudah mengujicobakan hal ini dengan menerima 10 keluarga dan mereka tidak harus membayar biaya pemrosesan visa yang bisa mencapai $\$ 75$ ribu (sekitar Rp 750 juta). ${ }^{1}$

Dengan diberikaannya bantuan kemanusiaan oleh Australia kepada Suriah tersebut, cukup menarik untuk menyoroti bagaimana respon Australia dalam menanggapi isu konflik Suriah bagi negara mereka, juga faktor apa saja yang menyebabkan Australia memberikan bantuan keamanan kepada Suriah. Berdasarkan fakta yang terjadi, maka pemberian bantuan keamanan tersebut menimbulkan beragam reaksi dari beberapa pihak. Oleh karena itu, penelitian ini kemudian mencoba mengajukan pertanyaan: (1) Apa saja kebijakan yang dirumuskan dalam pelaksanaan politik luar negeri Australia? (2) Apa saja kepentingan nasional dalam pelaksanaan politik luar negeri Australia? (3) Bagaimana kondisi domestik Australia?

\section{B. TINJAUAN TEORITIS}

(1) Konsep Politik Luar Negeri, Politik luar negeri merupakan rangkaian kebijakan otoritatif dari suatu negara terhadap dunia luar, dipengaruhi dan dibentuk oleh berbagai faktor internal dan eksternal yang saling berinteraksi. Politik luar negeri menggambarkan suatu tindakan negara yang mengarah pada situasi tertentu yang dipengaruhi oleh kondisi, ruang dan waktu, baik dipengaruhi oleh kondisi domestik maupun kondisi internasional.,Pollitik (kebijakan) luar negeri adalah strategi yang dirumuskan oleh elit politik suatu negara dalam hubungannya dengan negara lain untuk memperoleh, memperjuangkan, dan mempertahankan kepentingan nasionalnya

\footnotetext{
${ }^{1}$ https://news.detik.com/australia-plus-abc/d-3575467/pengungsi-suriah-langsung-dapat-visa-keaustralia
} 
(national interest) melalui jalan (instrumen) diplomasi ataupun perang.; (2)

kepentingan nasional, Pengambilan kebijakan luar negeri suatu negara didasarkan pada kepentingan nasional negaranya. Kepentingan nasional seringkali dipakai sebagai alat untuk menganalisa guna mengetahui tujuan kebijakan luar negeri suatu negara. Kepentingan nasional merupakan unsur yang menjadi kebutuhan sangat vital bagi negara, sehingga dalam pelaksanaan politik luar negeri suatu negara kepentingan nasional senantiasa diperjuangkan, dipertahankan, bahkan jika memungkinkan diperluas. Ia merupakan keseluruhan nilai atau unsur yang dicita-citakan dan hendak ditegakkan oleh suatu bangsa pada saat ini maupun masa mendatang. Unsur-unsur vital tersebut paling tidak mencakup kelangsungan hidup bangsa dan negara, kemerdekaan, keutuhan wilayah, kesejahteraan ekonomi, prestis internasional, dll.[kepentingan nasional dalam hubungan internasional secara umum digunakan dalam dua hal yaitu, sebagai alat untuk mengidentifikasi tujuan atau objektif dari suatu kebijakan luar negeri dan sebagai konsep politik yang digunakan untuk membenarkan suatu kebijakan politik tertentu. Dari kedua hal tersebut, kepentingan nasional merujuk pada kebijakan suatu negara dalam hubungan luar negeri. Sehingga hanya diaplikasikan pada negara yang berdaulat yang berhubungan dengan kebijakan luar negeri. Sebagai instrumen analisa politik, kebijakan nasional secara khusus diasosiasikan dengan teori politik realisme dan salah satu cendekiawan yang sangat berpengaruh Hans Morgenthau (1951). Menurut Morgenthau, kepentingan nasional merupakan istilah untuk kekuatan motif utama dari tindakan negara. ${ }^{2}$ Dari dua pengertian tersebut, penulis mengambil kesimpulan bahwa kepentingan nasional merupakan motif atau latar belakang dari kebijakan luar negeri suatu negara. Kepentingan nasional masing-masing negara dalam perpolitikan internasional tercermin dari kebijakan luar negerinya; (3) politik luar negeri, dalam hal ini peneliti mendapati banyak tinjauan untuk menjelaskan konsep politik luar negeri. Menurut Rosenau (1987) politik luar negeri sebagai sebuah aksi otoritatif oleh pemerintah, yang dikalkulasi dengan cermat dan memiliki tujuan dasar yang jelas. ${ }^{3}$ Kemudian menurut Wilkenfeld (1980) berargumen bahwa politik luar negeri lebih merupakan aksi reaksi yang resmi dari suatu negara berdaulat, dengan tujuan menciptakan suatu

\footnotetext{
${ }^{2}$ Evans, Graham; Newnham Jeffrey, (1998). The Penguin Dictionary of International Relations. 1st ed. London: Penguin Group.

${ }^{3}$ Rosenau, J. N. (1987). Introduction: New directions and recurrent questions in the comparative study of foreign policy. In C. F. Hermann, C. W. Kegley Jr., \& J. N. Rosenau (Eds.), New directions in the study of foreign policy. Boston: Allen \& Unwin.
} 
kondisi maupun mengubah kondisi yang sudah ada, dalam konteks di luar batas-batas territorial negara tersebut. ${ }^{4}$ Dari kedua pemahaman tersebut yang kemudian memunculkan asumsi peneliti bahwa politik luar negeri merupakan aksi reaksi atas isu yang ada. Politik luar negeri juga merupakan kepanjangan tangan dari politik atau kebijakan domestik negara, menurut Holsti (1963) dimana ide dan kebijakan (policy) merupakan bagian dari politik luar negeri suatu negara. Adanya perubahan situasi pada lingkungan internasional berpengaruh terhadap perilaku dan tindakan negara. ${ }^{5}$ Pengaruh individu atau kelompok pada level domestik suatu negara dapat mempengaruhi politik luar negeri suatu negara. Beberapa fitur utama politik luar negeri adalah bahwa ia disusun dalam kondisi domestik dan internasional yang kompleks, bahwa ia berupa resultan kepentingan dari aktor-aktor domestik dan internasional, bahwa isu yang diangkat selalu terkait kepentingan aktor. Negara sebagai aktor utama dalam studi hubungan internasional. Dari beberapa pengertian diatas, dapat disimpulkan bahwa politik luar negeri adalah sikap atau kebijakan yang dikeluarkan negara sebagai bentuk respon atas isu yang terjadi dalam politik internasional.

\section{METODE PENELITIAN}

Metode penelitian yang digunakan dalam penelitian ini adalah metode penelitian kualitatif, yaitu prosedur yang menghasilkan data yang deskriptif berupa kata-kata tertulis atau lisan dari orang-orang dan perilaku yang diamati. Metode deskriptif adalah suatu metode dalam meneliti status kelompok manusia, suatu obyek, suatu set kondisi, suatu sistem pemikiran maupun suatu kelas peristiwa pada masa sekarang. Tujuan dari penelitian deskriptif adalah untuk membuat deskripsi, gambaran atau lukisan secara sistematis, faktual, akurat mengenai fakta-fakta, sifat-sifat serta hubungan antar fenomena yang diselidiki. ${ }^{6}$

Dalam metode ini penulis berusaha mendeskripsikan politik luar negeri Australia terkait bantuan kemanusiaan ke Suriah. Peneliti mengumpulkan data dari perpustakaan yang relevan dengan penelitian ini.

\footnotetext{
${ }^{4}$ Wilkenfeld, J. et al. (1980). Foreign policy behaviour: The interstate behaviour analysis model. London: Sage.

${ }^{5}$ Holsti, K. J. (1983). International politics: A framework for analysis . 4th ed. London: Prentice Hall.

${ }^{6}$ Moh. Natsir, Metode Penelitian, Ghalia Indonesia (Jakarta:1988), hal.63
} 


\section{PEMBAHASAN}

\section{D.1. Faktor Konflik Suriah}

Ada banyak perspektif mengenai apa saja faktor yang melatarbelakangi pecahnya konflik Suriah. Sebuah konflik memang terjadi tidak disebabkan oleh sebab tunggal. Konflik selalu lahir dari sebab yang kompleks dan diliputi oleh banyak faktor dan kepentingan. Dan jika melihat peta konflik Suriah yang terjadi, terlalu sederhana (simplikatif) untuk menyatakan bahwa konflik tersebut tirani versus demokrasi, atau apalagi berlatar belakang teologis: perseteruan antara Sunni dan Syiah ${ }^{7}$. Karena sejarah Suriah adalah harmoni antar sekte dan umat beragama. Itu pula yang saya rasakan selama hidup di sana.

Ada empat faktor yang terlibat dalam sebuah konflik, yaitu triggers (pemicu), pivotal (akar), mobilizing (peran pemimpin) dan aggravating (faktor yang memperburuk atau memperuncing situasi konflik). Untuk mengetahui keempat faktor tersebut diperlukan sebuah analisis berupa kajian sistematis terhadap profil, sebabsebab, aktor, dan dinamika konflik. Klasifikasi faktor juga bisa dilakukan dengan melihat yang primer, sekunder dan tersier.

Intinya, secara global faktor penyebab konflik Suriah bisa dipetakan dalam dua hal:

1. Masalah internal (dalam negeri) Suriah, berupa terbatasnya kesempatan pergerakan/mobilitas sosial dan politik, kesenjangan, korupsi, dan represi aparat keamanan, serta tuntutan reformasi atas rezim klan Assad yang telah berkuasa selama 40 tahun. Anehnya, tuntutan reformasi ini tidak terjadi di delapan negara monarki yang juga tergabung dalam liga Arab yang tidak lebih demokratis. Jadi sejatinya yang terakhir ini tidak cukup kuat.

2. Masalah eksternal (luar negeri), berupa kepentingan politik, keamanan, dan ekonomi. Ini tidak lepas dari fakta bahwa Suriah adalah negara yang kuat secara militer dan selalu menunjukkan sikap perlawanan dan ancaman terhadap Israel sejak awal sejarahnya, termasuk dengan bersekutu bersama Iran, Hamas dan Hizbullah. Kondisi demikian membuat Israel, Amerika, NATO dan sekutunya di Timur Tengah turut berkepentingan mereformasi dan menumbangkan Assad. Demikian ringkasnya kebutuhan politik dan keamanan negara sekeliling Suriah.

\footnotetext{
${ }^{7}$ https://news.detik.com/kolom/d-3398935/memahami-konflik-suriah-tragedi-kemanusiaan-terbesarabad-21, diakses pada tanggal 15 Nopember 2017, jam 17.00 Wib
} 
Sementara dari sisi ekonomi, di balik koalisi Barat dan sekutu Arab, serta Turki terdapat kepentingan untuk mengeksploitasi cadangan minyak, di samping gas, dengan ketebalan sekitar 350 meter, berkali lipat rata-rata ketebalan kandungan minyak dunia yang hanya sekitar 10-20 meter di tanah milik Suriah. Sumber ini berisi miliaran barel yang kandungannya dapat membuat negara mana pun menjadi pemain minyak penting.

\section{D.2. Kepentingan Australia terhadap Konflik Suriah}

Kebijakan luar negeri Australia berpatokan pada tujuan dan kepentingan nasional yang ingin dicapai. Berikut ini adalah mengenai Tujuan Nasional dan Kepentingan Nasional Australia:

a) Tujuan Nasional Australia

Tujuan dasar politik luar negeri Australia adalah menjaga integritas dalam lingkungan internasional yang saling bersaing. Integritas suatu bangsa bukan hanya mencakup perlindungan terhadap aset-aset yang penting seperti wilayah teritori, sumber daya alam dan manusia dalam batas negara tetapi juga memelihara sistem ekonomi, politik, sosial, budaya masyarakat yang turun temurun secara singkat. Halhal tadi disebut sebagai etos fisik dan sosial dari sebuah negara. Ada dua sikap kelompok nilai yang membangun etos nasional Australia. Sikap kelompok nilai yang pertama adalah campuran antara nilai budaya, etika, agama dan etnis yang menentukan sikap dan moralitas masyarakat. Sedangkan kelompok nilai yang kedua adalah campuran antara nilai, sosial, politik dan ekonomi yang dipelihara oleh masyarakat dalam aturan-aturan administrative. Tujuan utama dari politik luar negeri suatu Negara adalah kelangsungan hidup dan untuk itu keamanan Negara adalah suatu hal yang mutlak. Keamanan Negara bukan hanya keamanan secara fisik dari serangan maupun invasi, tetapi berarti juga perlindungan dari agresi ekonomi Negara lain, yang juga berarti mengamankan dasar nilai dan budaya masyarakat dari penerapan ideologi luar negeri yang bertentangan.

b) Kepentingan Nasional Australia

Dalam melihat kepentingan nasional Australia, terdapat empat prioritas pokok:

1. Memelihara keamanan yang positif dan lingkungan strategis dalam kawasannya. Berarti Australia memiliki kepentingan langsung dalam menjamin situasi yang aman dan damai di Negara-negara sekitarnya agar tetap terpelihara dengan stabil.

2. Mendukung terciptanya keamanan global. 
3. Kerjasama ekonomi, investasi dan perdagangan. Australia ingin memobilisasi pengaruh politik internasional untuk mendukung tujuan ekonomi internasional dengan cara membuka pasar barang ekspor, memperluas kesempatan-kesempatan ekonomi bagi sektor industri Australia dan terus menciptakan persepsi bahwa Australia merupakan tempat yang menarik untuk melakukan penanaman modal asing serta menempatkan pemerintah Australia sebagai mitra yang ideal untuk kerjasama.

4. Menjadi warga dunia yang baik dengan Australia terus memainkan peranan yang positif dan konstruktif diantara aneka ragam isu yang sekarang menjadi subyek diplomasi multilateral, seperti penanganan masalah pengungsi, terorisme, perdagangan obat-obatan terlarang dan masalah kesehatan dunia. ${ }^{8}$

Berdasarkan Tujuan dan Kepentingan Nasional Australia yang telah ditetapkan oleh Pemerintah Australia, Perdana Menteri Howard pada masa pemerintahannya menetapkan kebijakan politik luar negerinya sebagai berikut:

a) Melindungi teritorial Australia dari serangan fisik dan memelihara kapasitas Australia dalam membuat kebijakan independen.

b) Membangun dan melanjutkan kapasitas kompetensi perdagangan dan investasi pada skala internasional, tapi dengan penekanan pada pasar Asia-Pasifik.

c) Menghapuskan senjata pemusnah massal dan untuk menahan konflik regional (di dalam dan diluar Asia), peningkatan keamanan dalam menghadapi terorisme internasional, melalui migrasi tidak sah, tentang penyakit, arus pengungsi, penurunan kualitas lingkungan, narkotika dan kejahatan transnational, sehingga dapat meminimalisasikan risiko konflik global.

d) Memelihara dan mempromosikan Australia sebagai negara yang memiliki nilai demokrasi liberal yang direfleksikan dari intelektual Eropa dan peninggalan budaya, untuk menarik minat negara-negara Asia Pasifik yang memiliki sejarah dan budaya yang berbeda. ${ }^{9}$

Kebijakan luar negeri Australia sangat ditentukan oleh berbagai faktor baik dari faktor internal maupun eksternal. Faktor-faktor internal dan eksternal yang amat mempengaruhi kebijakan luar negeri Australia antara lain:

\footnotetext{
${ }^{8}$ Peter,Brown, 2012. Australian Influence in South Pacific. Canberra: Australian Defence College, hal. 44

9 Hudson, V. M. (2007). Foreign policy analysis: Classic and contemporary theory.Maryland: Rowman \& Littlefield., hal.17.
} 
Pertama, "Historical Culture" atau budaya historis dan demografis. Dari sisi budaya historis dan demografis ini, ada dua negara yang amat berpegaruh dalam pembentukan kebijakan luar negeri Australia, yaitu Inggris dan Amerika. Kedua, adalah faktor geografis. Sebagai Negara benua di selatan khatulistiwa yang dihuni oleh sebagian besar masyarakat keturunan inggris (Anglo Celtic), masyaraka Australia merasa terisolir oleh lingkungan luarnya. Ketiga, perubahan konstelasi politik, ekonomi, dan keamanan regional dan internasional tidaklah bersifat statis melainkan dinamis. Keempat, tujuan yang inin diraih dari kebijakan luar negeri adalah kepentingan nasional. Tujuan politik dari kebijakan luar negeri Australia ini dapat disimpulkan kedalam empat hal: a) suatu Australia yang lebih aman, baik dari segi fisik, ekonomi, budaya, dan politi, termasuk ideology dan national etosnya; b) suatu dunia yang lebih aman; c) suatu dunia yang lebih kaya; d) suatu dunia yang lebih baik.

Kecenderungan politik luar negeri Australia untuk menjalin kerja sama dan membuka diri terhadap kawasan asia pasifik dengan tetap tidak meninggalkan hubungannya dengan AS dan inggris adalah langkah nyata arah kebijakan luar negeri Australia pada masa sekarang. Walaupun hubungannya dengan negara induk yakni Inggris sekarang agak melemah dikarenakan jarak antara Australia dan negara induk tersebut menyebabkan Australia lebih memilih untuk mendekatkan diri ke Amerika Serikat yang mana notabenenya memiliki pengaruh yang lebih kuat dari pada inggris di kawsan asia pasifik. Jadi menurut Australia hubungannya sebagai orang western tetap dijaga dengan kerjasama keamanan bersama AS selain itu untuk masalah kerjasama ekonomi dan lainnya Australia mulai membuka diri di kawasan asia pasifik. Sedangkan dengan kawasan regional asia pasifik Australia memberikan dukungan terhadap berbagai organisasi yang ada di kawasan asia pasifik ini. Dukungan tersebut terlihat pada organisasi berikut $:^{10}$

a) Pacific Islands Forum Secretariat (PIFS) adalah Forum Kepulauan Pasifik (sebelumnya dikenal sebagai Forum Pasifik Selatan sebelum 2000), yang pelayanan Sekretariat, menyatukan independen dan mengatur diri-negara di Pasifik dalam tahunan pemimpin sebuah KTT.

b) Secretariat of the Pacific Community (SPC)

\footnotetext{
${ }^{10}$ Henningham, Stephen, 1992. "Australia and the South Pacific”, dalam Australia in a Changing World, ed. F.A. Mediansky. Botany, NSW: Maxwell Macmillan Publishing Australia, hal 56
} 
c) South Pacific Applied Geoscience Commission (SOPAC) yang membantu anggota untuk menilai, eksplorasi dan pengembangan mineral dan sumber daya yang tidak hidup lainnya.

d) Pacific Regional Environment Program (SPREP) mempromosikan kerjasama regional dalam masalah lingkungandi asia pasifik.

e) Forum Fisheries Agency (FFA) yang bertujuan membantu anggota untuk memaksimalkan manfaat yang berkelanjutan dari konservasi dan pemanfaatan berkelanjutan sumber daya perikanan mereka.

f) South Pacific Board of Educational Assessment (SPBEA) yaitu suatu daerah, organisasi antar pemerintah yang didirikan pada tahun 1980 untuk membantu negaranegara anggota dan wilayah untuk mengembangkan prosedur penilaian terhadap dan / atau regional sertifikat nasional.

g) University of South Pacific (USP) yang merupakan penyedia utama pendidikan tersier diwilayah Pasifik dan pusat internasional keunggulan untuk pengajaran, penelitian dan konsultasi pada semua aspek kehidupan Pasifik.

h) Fiji School of Medicine (FSMed) yang merupakan lembaga kesehatan tersier yang melatih dan mendidik profesional kesehatan untuk melayani masyarakat di Pasifik.

Selain dukungan Australia juga merupakan anggota dari organisasi regional Asia Pasifik yaitu:

a) APEC yaitu program kerjasama ekonomi di kawasan asia-pasifik.

b) ASEAN-Australian Development Cooperation Programme (AADCP) Program Kerjasama Pembangunan ASEAN-Australia adalah demonstrasi praktis dari komitmen Australia untuk bekerja sama dengan ASEAN untuk meningkatkan pembangunan ekonomi dan sosial yang berkelanjutan di Asia Tenggara. Hal ini mencerminkan prioritas saat ini dan tantangan yang dihadapi kedua pasangan untuk memperluas hubungan ekonomi, meningkatkan pertumbuhan ekonomi dan meningkatkan keamanan di kawasan negara-negara dengan tantangan pembangunan yang berbeda. Tujuan dari program ini adalah untuk mempromosikan pembangunan berkelanjutan di dalam ASEAN, dengan membantu ASEAN untuk mengatasi tantangan pembangunan daerah prioritas melalui kerjasama regional.

Tujuan khusus dari AADCP adalah:

1. untuk memperkuat kerjasama ekonomi dan sosial regional (termasuk-ekonomi dan keuangan kerjasama makro, integrasi ekonomi, perumusan kebijakan sosial dan sistem, dan hubungan AFTA-CER). 
2. untuk memperkuat kapasitas kelembagaan daerah

3. untuk memperkuat ilmu pengetahuan, teknologi dan kerjasama lingkungan;

4. untuk mempercepat baru Negara-negara Anggota ASEAN 'integrasi ke ASEAN dengan mendukung partisipasi mereka dalam program-program kerjasama ASEAN.

Australia duduk dalam Dewan Keamanan PBB dengan periode dua tahun mulai 2013. Tahun 2014, ia mendorong resolusi bantuan kemanusiaan di SuriahPenelitian ini mengajukan argumentasi yaitu respon Negara Australia dan warga negara Australia terhadap konflik Suriah. ${ }^{11}$ Tiga kategori tersebut adalah mendukung, ambivalen dan menentang. Mendukung dalam hal ini adalah dimana respon suatu negara yang merasa diuntungkan dengan memberikan bantuan kemanusiaan kepada Suriah, Australia. Ambivalen adalah reaksi suatu negara yang tidak berada dalam golongan pro dan kontra melainkan lebih menyikapi konflik Suriah tersebut sebagai posisi yang dapat menguntungkan tetapi juga dapat merugikan bagi kepentingan negaranya, posisi negara tersebut cenderung berubah-ubah menyesuaikan kondisi menurut kepentigan nasional bagi negaranya. Menentang dalam hal ini adalah satu reaksi yang muncul dimana suatu negara tidak merasa diuntungkan, namun justru merasa kepentingannya terancam atau merasa dirugikan drengan mengirimkan bantuan kemanusiaan terhadap konflik Suriah. Penelitian ini menggunakan dua sisi pandangan yaiut pandangan faktor domestik Negara Australia, dan juga faktor kebijakan luar negeri Australia. Keduanya akan saling berhubungan dengan faktor kepentingan politik luar negeri Australia khususnya terhadap konflik Suriah.

\section{D.3. Bantuan Kemanusiaan ke Suriah}

Bantuan kemanusiaan Australia bekerja sama dengan PBB dan organisasi non - pemerintah yang netral untuk memberikan bantuan kemanusiaan bagi warga sipil yang terkena dampak perang saudara Suriah. Sejak 2011, Australia telah menyediakan lebih dari \$ 130 juta dalam bantuan kemanusiaan untuk membantu orang di dalam

\footnotetext{
${ }^{11}$ https://www.hrw.org/id/world-report/2015/country-chapters/268177, diakses 13 Nopember 2017, jam $16.00 \mathrm{Wib}$
} 
Suriah dan pengungsi Suriah di Timur Tengah. Pendanaan Australia telah membantu Program Pangan Dunia untuk memberi makan 4.250.000 orang di dalam Suriah setiap bulan dan mendukung Dana Anak PBB ( UNICEF) untuk memastikan 10 juta orang memiliki akses terhadap air bersih. Pemerintah Australia juga menyediakan logistik dan layanan perlindungan anak di kamp-kamp pengungsi di perbatasan Suriah.

Pada tahun 2016 di Konferensi Donor-Donor Suriah bahwa Australia akan memberikan tambahan senilai AU\$ 25 juta untuk bantuan kemanusiaan penyelamatan jiwa di Suriah, Irak dan negara-negara di kawasan yang menampung sejumlah besar pengungsi. Pendanaan baru ini termasuk \$ 20 juta untuk mitra dalam wilayah Suriah, dan untuk mitra yang beroperasi di wilayah termasuk Komisaris Tinggi PBB untuk Pengungsi (UNHCR), Badan PBB untuk Anak (UNICEF), Program Pangan Dunia (WFP) dan LSM Australia ${ }^{12}$. Bantuan Australia akan memungkinkan pengungsi Suriah dan masyarakat tuan rumah pengungsi untuk mengakses sumber-sumber penting seperti makanan, tempat tinggal dan perlindungan.

Pemerintah Australia juga akan memberikan tambahan senilai \$ 5 juta untuk Irak, termasuk \$ 2 juta untuk United Nations Development Programme untuk membantu menstabilkan wilayah di negara yang dibebaskan dari ISIS, dan bantuan untuk mitra LSM. Peningkatan kontribusi ini akan mendukung warga sipil yang terkena dampak krisis kemanusiaan terburuk di dunia. Di Suriah, sebanyak 13,5 juta orang membutuhkan bantuan kemanusiaan yang mendesak. Sebanyak 4,6 juta warga Suriah adalah pengungsi di negara-negara tetangga. Diperkirakan 10 juta orang di Irak juga membutuhkan bantuan kemanusiaan yang mendesak tahun ini.

Selain penambahan dana kemanusiaan ini, Pemerintah Australia juga akan mengerahkan 10 orang spesialis dari Korps Sipil Australia ke Libanon dan Yordania untuk membantu mitra PBB dan LSM memberikan pendidikan, air, sanitasi, infrastruktur tempat pengungsian, logistik dan perlindungan untuk pengungsi Suriah. Pengumuman ini membuat respon kemanusiaan Australia terhadap krisis Suriah menjadi lebih dari \$213 juta sejak 2011, dan untuk Irak mencapai \$45 juta sejak tahun 2014, dengan total bantuan sebesar \$258 juta.

Untuk memperlihatkan kekhawatiran Australia pada gangguan oleh kekerasan rezim Suriah terhadap rakyatnya, Australia menerapkan sanksi baru terhadap Suriah pada 21 Agustus 2012 yang membatasi perdagangan logam mulia dan berlian, barang-

\footnotetext{
${ }^{12}$ http://indonesia.embassy.gov.au/jaktindonesian/MR16_011.html, diakses 14 Nopember 2017, jam $17.00 \mathrm{Wib}$
} 
barang mewah, dan baru dicetak mata uang dan juga dengan sektor minyak, gas dan petrokimia. Langkah-langkah baru menambah pembekuan aset yang ada dan larangan perjalanan pada 106 individu dan 28 entitas dan embargo pada penyediaan peralatan militer dan bantuan. Sanksi Australia secara khusus menargetkan rezim, bukan rakyat Suriah . termasuk sanksi terhadap tokoh-tokoh senior pemerintah, termasuk Presiden Assad, yang terhubung dengan kekerasan dan pelanggaran hak asasi manusia. Apa yang dapat mereka lakukan untuk membantu? Pertama, Membuat sumbangan kepada badan PBB atau organisasi non - pemerintah ( NGO ) yang memberikan bantuan kemanusiaan di dalam dan sekitar Suriah (lihat lembar informasi pada penyediaan bantuan keuangan. Kedua, Berpartisipasi dan terlibat dalam kegiatan aksi damai, Ketiga, Menulis ke Senator atau Wakil Federal Parlemen - yang terpilih untuk mewakili mereka. Keempat, Gunakan media sosial dan bertanggung jawab untuk menyuarakan keprihatinan dan berkontribusi untuk menantang rezim Suriah

\section{E. KESIMPULAN}

Dari gambaran analisis dan penjelasan singkat yang dibuat oleh peneliti, maka peneliti menarik kesimpulan inti bahwa faktor-faktor yang menyebabkan Australia mau memberikan bantuan kemanusiaan kepada Suriah karena disebabkan oleh faktor kepentingan negara, faktor politik luar negeri Australia dan faktor domestik Australia. Adanya faktor-faktor tersebut membentuk pandangan suatu negara dalam menyikapi konflik Suriah.

Faktor kepentingan nasional lebih mengarah ke keamanan nasional Australia.Pendekatan Pemerintah mempunyai empat tingkat: memelihara masyarakat yang tangguh, multikultural, membantu lembaga-lembaga dan sektor-sektor masyarakat kita memerangi ideologi ekstrimis kekerasan di mana pun hal ini muncul, menantang dan merongrong daya tarik propaganda teroris, khususnya daring, dan tangan untuk mengalihkan individu dari pandangan-pandangan ekstrim kekerasan mereka. Yang lebih penting lagi, pemerintah tidak dapat memenangi pertempuran ini sendiri saja. Para tokoh masyarakat dan kelompok mempunyai tanggung jawab besar baik dalam mengutuk ekstrimisme kekerasan dan mengajar persatuan dalam keanekaragaman, saling hormat bukannya kebencian. Dengan memberikan bantuan ke Suriah setidaknya keamanan Australia akan terjaga.

Dalam menyikapai konflik Suriah, Australia terkesan tidak agresif. Bahkan Pemerintah Australia mendapat tekanan dari kelompok-kelompok HAM untuk 
menampung lebih banyak pengungsi Suriah. Salah satu dari kebijakan terakhir Perdana Menteri Tony Abbott yang dipecat, adalah mengumumkan rencana memberi suaka kepada 12 ribu warga Suriah dari kelompok “minoritas yang teraniaya”.Dalam kelompok-kelompok tertentu, terdapat tentangan yang sangat kuat untuk membantu para pencari suaka dari Timur Tengah. Imigrasi tetap menjadi masalah yang paling memecah-belah Australia, dan PM Malcolm Turnbull, yang dikenal karena pandangan progresifnya, akan sangat menyadari bahwa kebijakan suaka yang keras itu membantu kelompok konservatif mendapat kemenangan besar dalam pemilu. 


\section{Daftar Pustaka}

Brown, Peter, 2012. Australian Influence in South Pacific. Canberra: Australian Defence College.

Cotton, James, 2006. “Australian Foreign Policy and the Management of Intelligent in Post September 11", dalam Asia Pacific School and Economic and Government. Melbourne: Australia National University.

Evans, Graham; Newnham Jeffrey, (1998). The Penguin Dictionary of International Relations. 1st ed. London: Penguin Group.

Gyngell, Allan, 2007. Australia and New Zealand in a Globalizing World. Sydney: The Lowy Institute for International Policy.

Henningham, Stephen, 1992. "Australia and the South Pacific", dalam Australia in a Changing World, ed. F.A. Mediansky. Botany, NSW: Maxwell Macmillan Publishing Australia.

Hudson, V. M. (2007). Foreign policy analysis: Classic and contemporary theory. Maryland: Rowman \& Littlefield.

McDougall, D., 1998. Australian Foreign Relations: Contemporary Perspectives. London: Longman Publishing.

Stevens, Christine A., 2002. Asylum Seeking in Australia. International Migration Review, 36 (3)

http://www.cnnindonesia.com/internasional/20150907065532-113-76995/australiaakan-terima-lebih-banyak-pengungsi-irak-dan-suriah/

http://mirajnews.com/id/internasional/australia/australia-siapkan-bantuan-untukpengungsi-suriah/

https://news.detik.com/australia-plus-abc/d-3575467/pengungsi-suriah-langsungdapat-visa-ke-australia 